
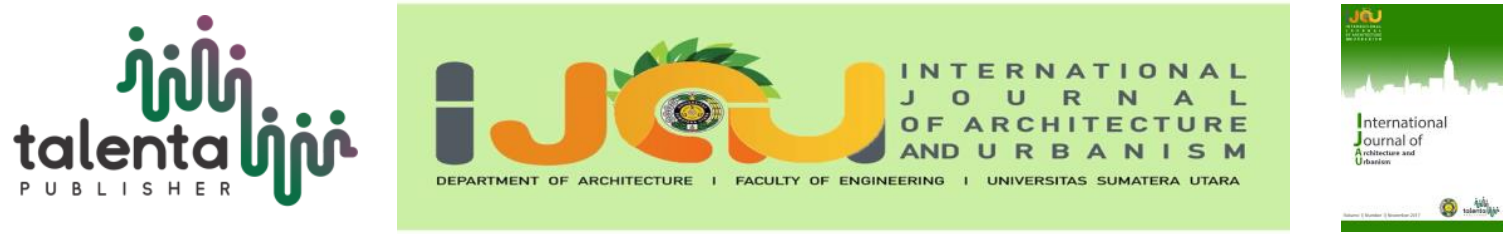

\title{
Analysis of the Evacuation Route Effectiveness Based on the Hotel's Visitor Evacuation Speed (Case Study: Grand Kanaya Hotel, Medan)
}

\author{
N. Vinky Rahman ${ }^{1 *}$, Lenita Aulia Sinaga ${ }^{1}$ \\ ${ }^{1}$ Architecture Department, Faculty of Engineering, Universitas Sumatera Utara, Medan, Indonesia
}

\begin{abstract}
The territory of Indonesia has geographical, geological, hierarchical and demographic conditions that enable disasters or emergencies, whether caused by natural or non-natural factors. When an emergency occurs, evacuation must be carried out as quickly and effectively as possible to minimize losses. Evacuation Emergency conditions are things that need to be considered by every building manager. However, until now buildings are still often found that are operating but have not met the requirements of building function worthy certificates. The hotel building is one of the buildings that need to be considered is the emergency response system and its evacuation route. The hotel building is a vertical residential building that has many users and activities, so it requires an optimal evacuation route. This study aims to analyze the effectiveness of evacuation routes in hotel buildings and recommend proper evacuation routes for a hotel building. A descriptive study was conducted to determine the existing conditions and simulations using Rockwell Arena software to determine the visitor's evacuation speed in hotel buildings. The results of the research and simulation of Rockwell Arena software indicate that the evacuation path in hotel buildings has not been sufficient so that design recommendations are needed to improve the effectiveness of evacuation routes. This research can be used as a reference and consideration for finding out the problems that exist on the evacuation routes in hotel buildings.
\end{abstract}

Keyword: emergency, evacuation route, simulation, hotel

\section{Introduction}

Emergency evacuation is something that needs to be considered by every building manager. The government has regulated this in Article 59 of the Republic of Indonesia Government Regulation No. 36 of 2005 about Regulations for Implementation of Law No. 28 of 2002 about

\footnotetext{
*Corresponding author at Architecture Department, Faculty of Engineering, Universitas Sumatera Utara, Jalan Perpustakaan Gedung J07, Medan 20155, Indonesia

E-mail address: vinkyrahman@gmail.com
} 
Building. The regulation has explained about Occupational Safety and Health (K3) standards and evacuation in high-rise buildings or regular buildings.

The achievement of safe evacuation in an emergency condition on buildings is one of the purposes of feasible building requirements (SLF). However, until now some buildings operate but have not met the SLF requirements.

A building that its emergency response system and evacuation route needs to be considered is a hotel building. The hotel building is a temporary vertical residential building which tends to have many visitors and activities. According to the Minister of Manpower Decree No. 186/MEN/1999, hotel buildings are included in the classification of mild fire hazard buildings. However, hotel buildings use interiors with materials that facilitate fire propagation such as carpets, wood, and paper [1].

The Grand Kanaya Hotel is a hotel building in North Sumatra. The number of room units in this hotel is quite high. There are 152 rooms in this hotel building, so it requires a good emergency evacuation route for all its visitors. The by analyzing the effectiveness of this evacuation route it is expected to examining the feasibility of the evacuation route and referring to the designers about proper design of evacuation route according to the standards in the hotel building.

\section{Literature Review}

Emergency conditions are events or series of events that are threatening and disrupting people's lives and livelihoods caused by natural factors and/or non-natural factors as well as human factors resulting in human deaths, environmental damage, property losses, and psychological impacts [2].

According to the Department of Labor (2003) emergencies are abnormal situations or events that occur suddenly and can disrupt community activities and need to be addressed immediately. According to Ministerial Decree SK 241/H/70 of 1970, Hotels are companies that provide services in the form of lodging or accommodation and provide meals and other facilities to the public that meet the requirements of comfort, commercial privacy, and purpose. According to the Ministry of Public Works (2012) evacuation is a direct and rapid movement of people away from threats or actual events of danger.

According to the Fire Training Guide Tk 1 (2002), it is stated that the evacuation route is a continuous exit or path that is unobstructed and must be passed by the user in the event of an emergency from any point/place in the building to a safer place. Evacuation route is the path used as a direct and rapid transfer of people who will stay away from threats or events that could endanger lives [3]. 
The element of Evacuation Route

The requirement for the distance of the corridor to the exit of each place must be not more than $20 \mathrm{~m}$ from the door to the outside, or from an area with a two-way lane to 2 doors out available if the maximum distance to one of the exits is not exceeding $40 \mathrm{~m}$ [4].

Every state building with a level total more than three floors, nine must have a minimum two emergency stairs with a maximum emergency distance/rescue $30 \mathrm{~m}$ (if using a sprinkler the distance can be 1.5 times or $45 \mathrm{~m}$ ). The minimum emergency/rescue stair width is $1.20 \mathrm{~m}$. Emergency/rescue stairs should not be in the form of a vertical circular staircase (Figure 1), exit on the ground floor directly to the outside [5].

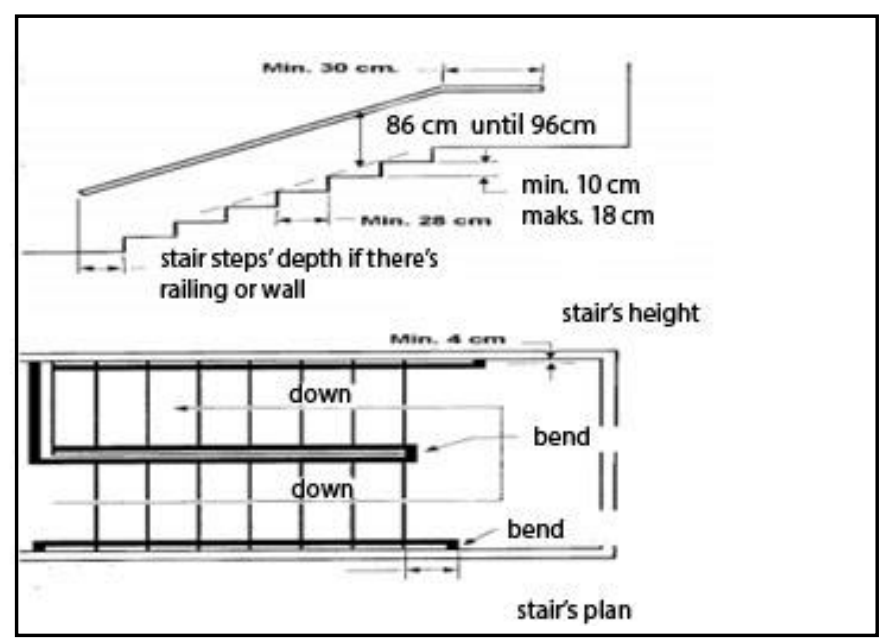

Figure 1. Stair Details

(Source: SNI 03-1746-2001)

Exits or pointing arrows must be placed at the intersection of the corridor, way out to the emergency staircase, balcony or terrace and the door to the emergency stairs. A clear exit sign will facilitate and speed up the evacuation process because it eliminates the dangers of building residents during the fire event [6].

The size of the direction sign that reads "EKSIT" or other suitable words, with letters that are easy to see, a height of at least $15 \mathrm{~cm}$, a letter thickness of at least $2 \mathrm{~cm}$. The word "EKSIT" must have a letter width of at least $5 \mathrm{~cm}$ except for the letter "I" and a minimum distance between letters of at least $1 \mathrm{~cm}$ (Figure 2). Larger direction signs are made with width, thickness, and length of messages proportional to their height. 




Figure 2. Signage standard size

(Source: SNI 03-6574-2001)

Each emergency lamp must work automatically and have a sufficient level of lighting for safe evacuation (minimum of $10 \mathrm{Lux}$ is measured on the floor). If you have a centralized system, one backup power and automatic control must be protected from damage due to fire with a cover construction that has a Fire Resistance Level (TKA) not less than 1 hour. Emergency lights used must be by applicable standards (Figure 3) [7].

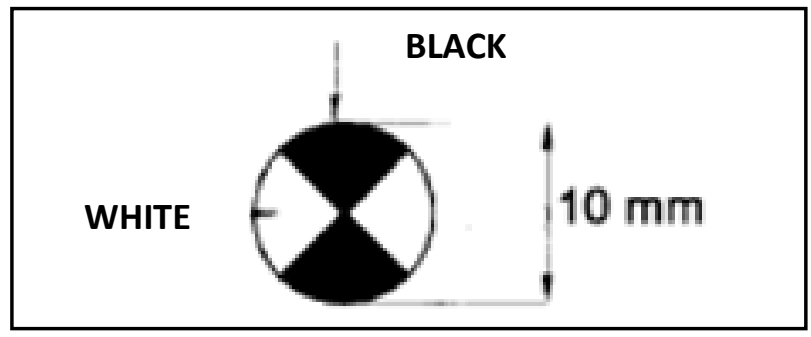

Figure 3. Emergency lamp Symbol Identification (Source: SNI 03-6574-2001)

In an evacuation of a building, all building users or occupants of the building are directed to an assembly point that should be easily accessible and safe enough from danger. Besides, the minimum space for one person when standing in groups is $70 \mathrm{~cm} 2$ per person [8].

Designers should design parts of a building that can ensure all users have enough time to save themselves in the event of an emergency. However, due to diverse users, structures and types of emergencies, it is challenging to estimate the exact duration [6]. Even so, most regulations and standards determine the period of the evacuation of some past events. The period most commonly used as a standard duration of removal is 2.5 minutes. Class 9 buildings must have a fire resistance structure of at least 60 minutes [9]. So it can be said for class 9 buildings that the effective evacuation time is less than 60 minutes

\section{Methodology}

The research location is a 3-star hotel located on Jalan Darussalam No. 12, Medan, North Sumatra, Indonesia (Figure 4). The hotel consists of 152 rooms with additional facilities such as restaurants, lounges, souvenir shops, meeting rooms, and ballrooms. Grand Kanaya Hotel Building includes of a single building. For this study, the author took a sample of the Grand Kanaya Hotel building which is a vertical residential building with six floors high (Figure 5). 


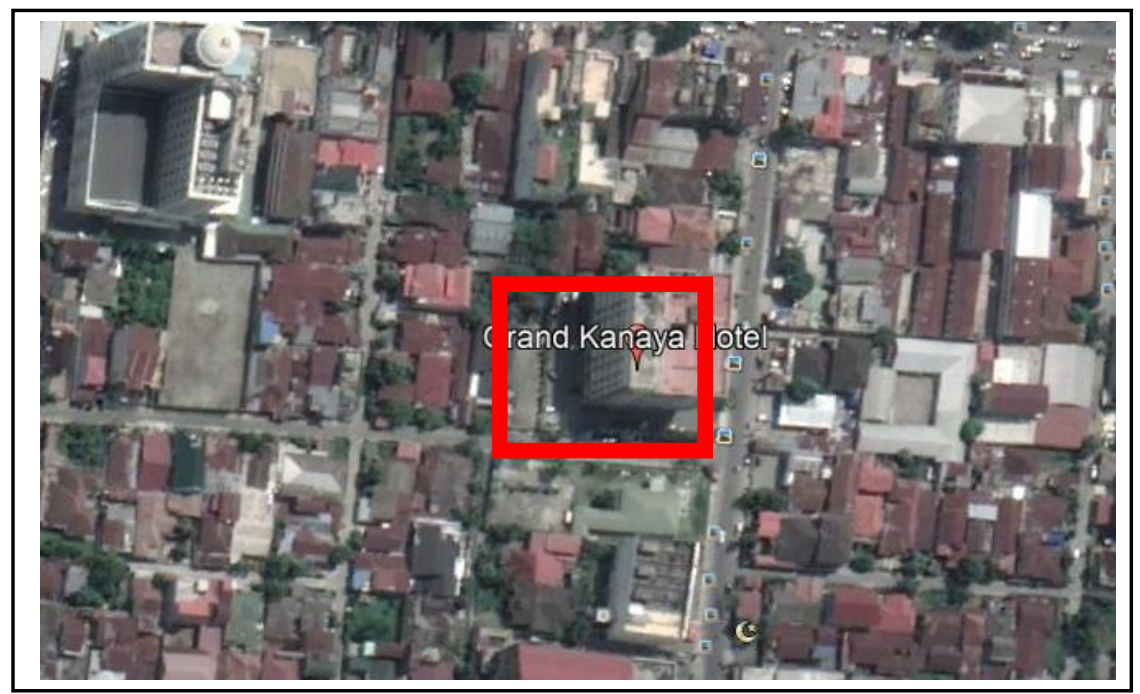

Figure 4. Location of Research Area

(Source: Google Earth, 2018)

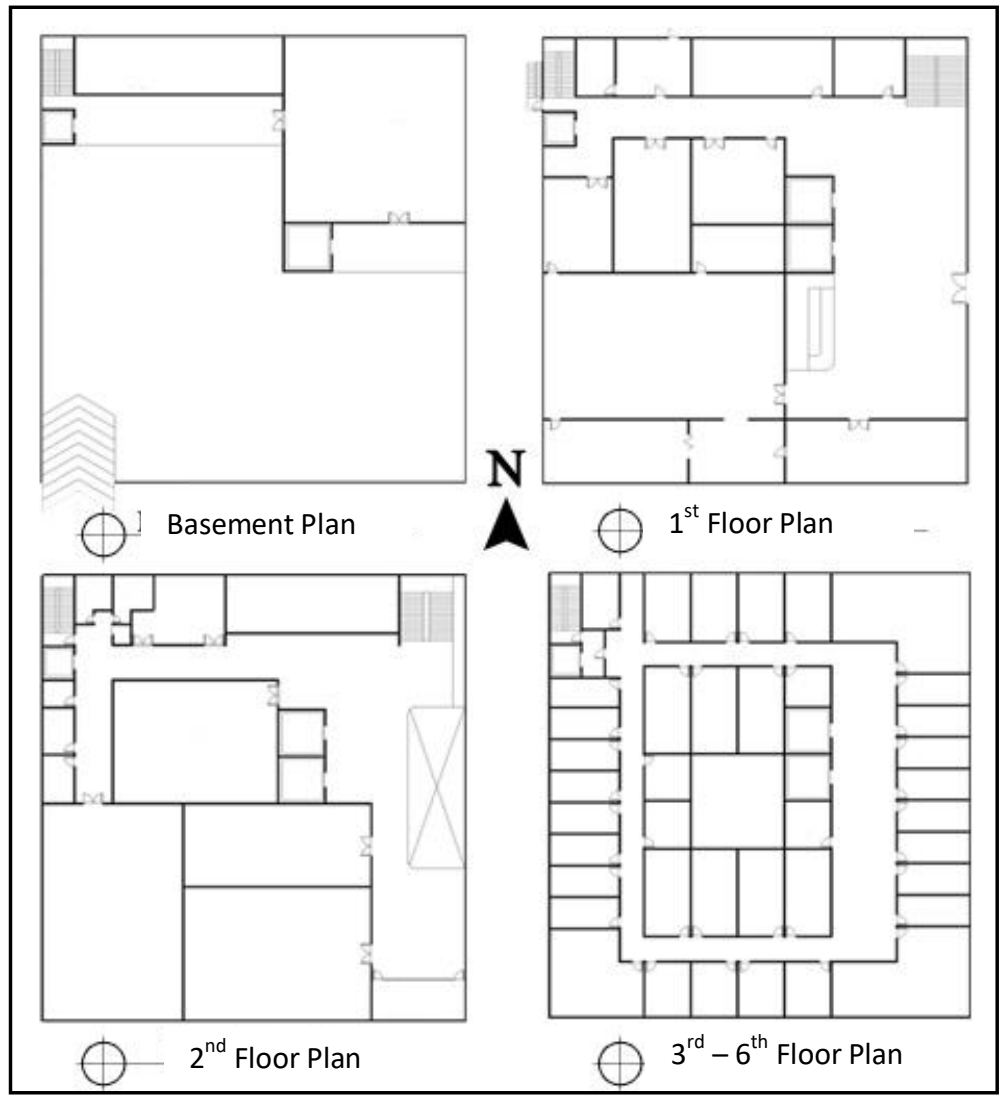

Figure 5. Grand Kanaya Hotel's Floorplans

To obtain the existing data from the evacuation route at Grand Kanaya Hotel, a descriptive study was conducted [10]. Meanwhile, to determine the speed of evacuation of residents at the Grand Kanaya Hotel, simulation methods were used using the Rockwell Arena software.

Arena software is a program that processes of designing a real system model in the field with the aim of understanding system behavior and evaluating it to improve the performance of a 
system. This software is equipped with an input analyzer that is useful to find out the distribution of a group of data.

The first step to finding the speed of evacuation is to make a hotel visitor evacuation route based on observations and field conditions. Then calculate the speed of the evacuation of individual locked based on the formula in NFPA 1995 (Method To Calculate The Travel Time)

$$
\mathrm{D}=\mathrm{p} / \mathrm{m}^{2}
$$

From the density of the occupants we can decide the particular speed of visitors, as follows (Table 1) :

Table 1. Every Variables Characteristic toward Condition and Facility Types

\begin{tabular}{ccccc}
\hline Type Of Facility & Condition & Density & Speed of person & Specific Flow \\
\hline Stairs (down) & Low & $<1,9$ & 1,0 & 0,54 \\
& Optimum & 1,9 to 2,7 & 0,50 & 0,94 \\
& Moderate & 2,7 to 3,2 & 0,28 & 0,77 \\
Stairs (up) & Crush & $>3,2$ & 0,3 & 0,42 \\
& Low & $<1,9$ & 0,8 & 0,43 \\
& Optimum & 1,9 to 2,7 & 0,40 & 0,75 \\
& Moderate & 2,7 to 3,2 & 0,22 & 0,62 \\
& Crush & $>3,2$ & 0,10 & 0,32 \\
& Low & $<1,9$ & 1,4 & 0,76 \\
& Optimum & 1,9 to 2,7 & 0,70 & 1,3 \\
& Moderate & 2,7 to 3,2 & 0,39 & 1,10 \\
& Crush & $>3,2$ & 0,18 & 0,55 \\
\hline
\end{tabular}

(Source: IMO's Interim Guidelines)

\section{Result and Discussion}

The maximum mileage in a hotel building is 45 meters. However, the current maximum distance on floors 3 to 6 reaches 51 meters, exceeding the standard. While the dimensions of the corridor are by the rule that is not less than 2 meters in height and a width of not less than 1 meter (Figure 6). 


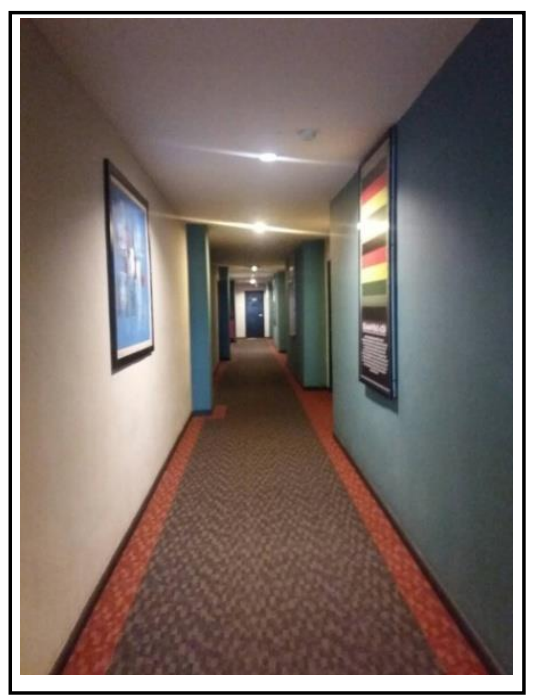

Figure 6. Corridor Condition

Buildings over three floors should have at least two emergency stairs, but Grand Kanaya Hotel only has one emergency stair. The emergency staircase door is by the standard by opening to the stairs but the material used is wood material that is flammable (Figure 7). The shape of the emergency staircase is appropriate (Figure 8). The emergency staircase exit is also proper, which is towards the outside of the building (Figure 9).

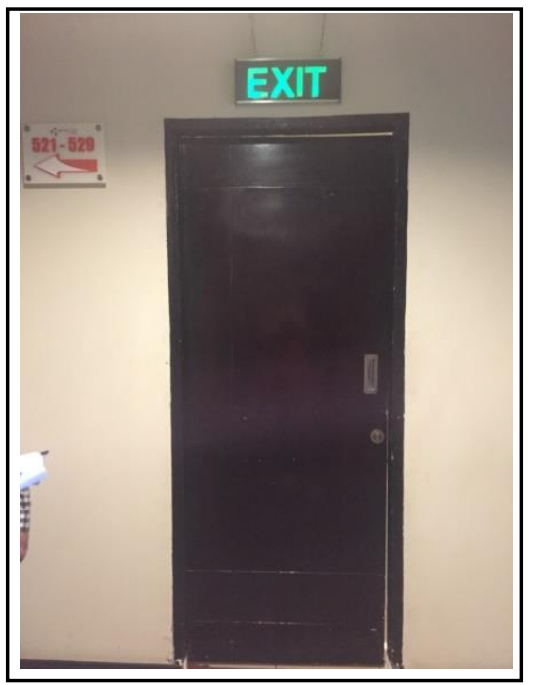

Figure 7. Exit Doors 


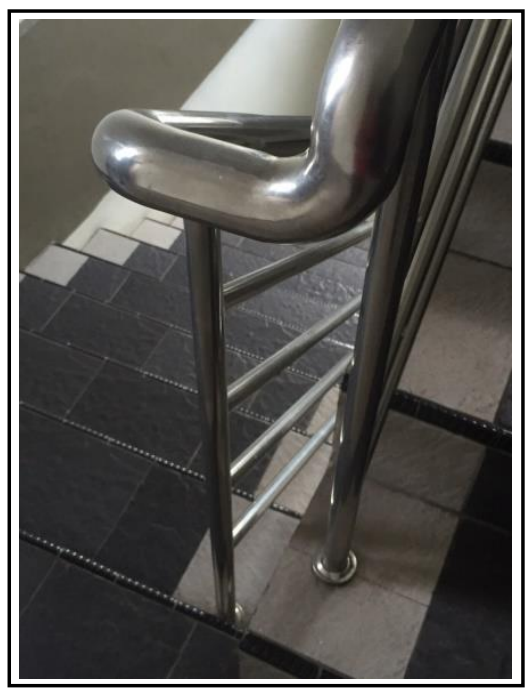

Figure 8. Emergency Stair

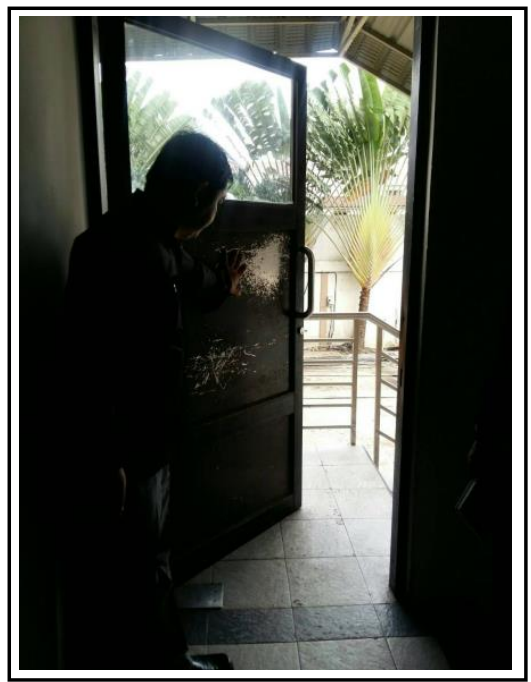

Figure 9. Exit toward Assembly Point

The size of the direction sign is appropriate so that it can be easily seen. The installation location of the directional sign is suitable, which is placed at the intersection of the corridor (Figure 10). The presence of emergency lights in the hallway is appropriate, but there are no emergency lights on the emergency stairs (Figure 11). Gathering point is available around the Grand Kanaya Hotel (Figure 12), the minimum area required is $658 \mathrm{~m} 2$, the open space is 680 $\mathrm{m} 2$ so that it is as needed. 


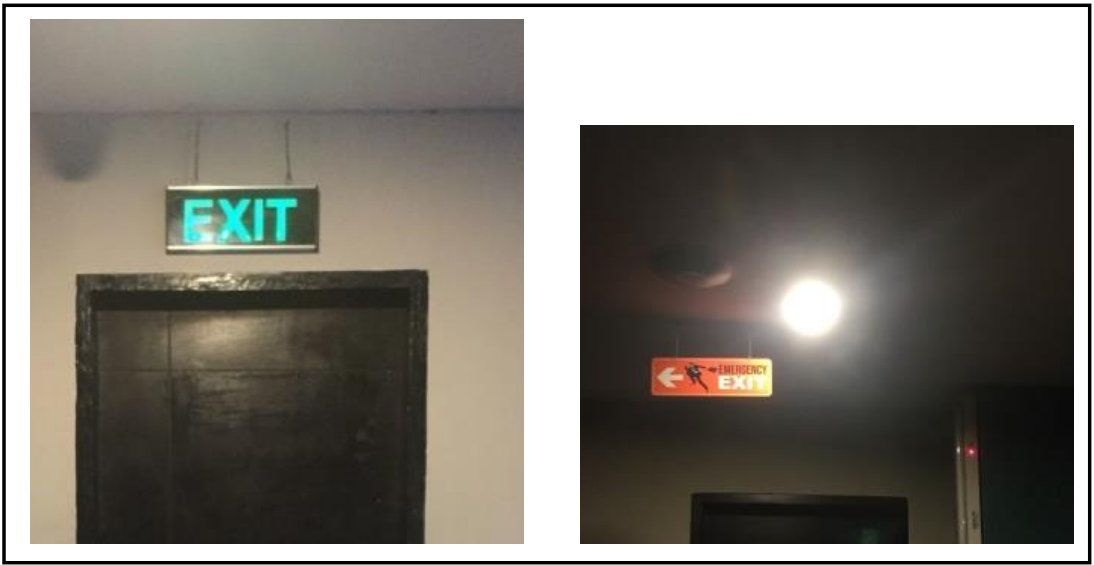

Figure 10. Exit Sign and its Location

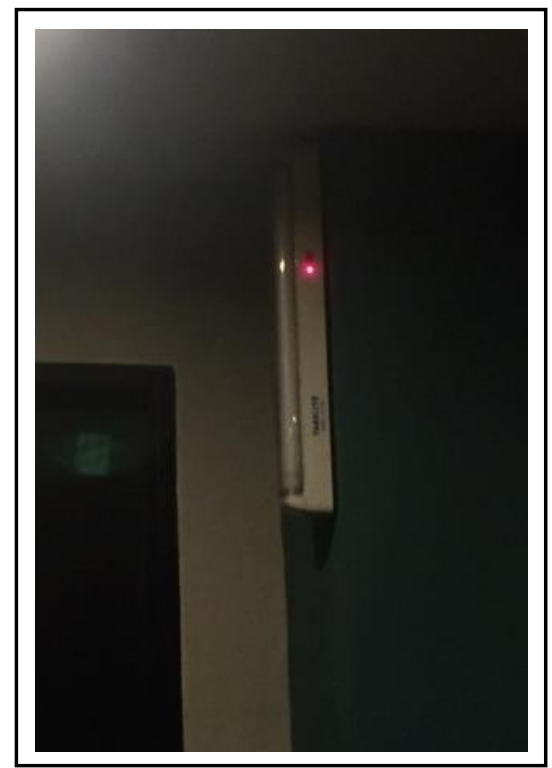

Figure 11. Location of Emergency Lamp

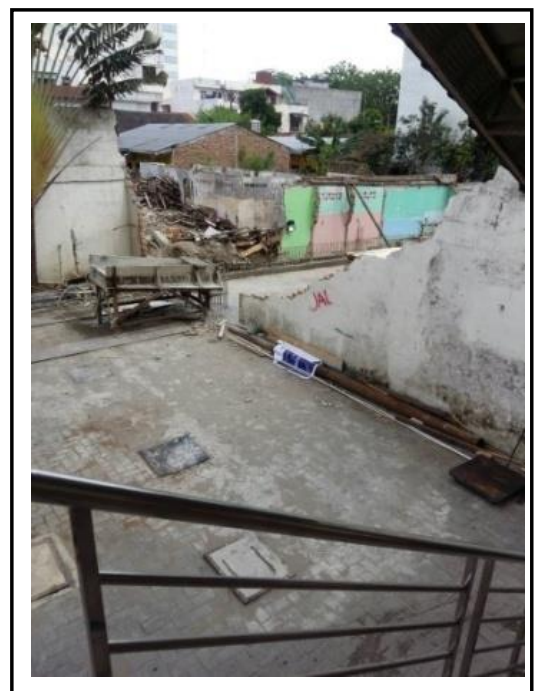

Figure 12. Assembly Point 


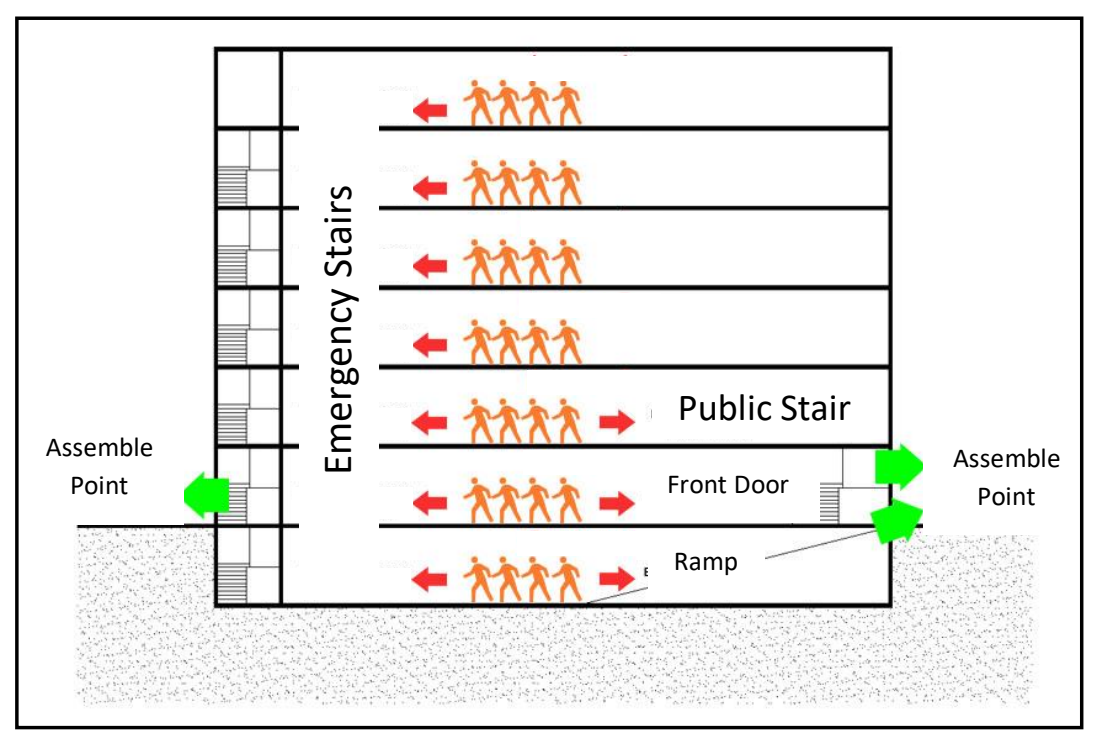

Figure 13. Schematic of Overall Evacuation Route

Overall, evacuation routes on floors 3 to 6 have only one exit option which is an emergency staircase. While on the 2 nd floor to the basement there is a standard staircase and ramp which is an alternative. When visitors arrive on the 1st floor, the exit is also divided into two, namely the emergency exit to the meeting point behind the building and the front door leading to the assembly point in front of the building (Figure 13).

On the 3rd to 6th floor corridors, the average arrival of each person to the emergency stairs is 19.08 seconds with the fastest time of 3.5 seconds and the longest time is 36.42 seconds. On the second floor corridor, the average arrival of each person to the emergency stairs was 21.5 seconds with the fastest time of 6.5 seconds and the longest time 46.8 seconds. On the 1st floor corridor, the average arrival of each person to the emergency stairs is 19 seconds with the fastest time of 4.2 seconds and the longest time is 34.28 seconds. In the basement corridor, the average arrival of each person to the emergency stairs is 17 seconds with the fastest time of 12 seconds and the longest time is 23 seconds. On the emergency stairs on the 2nd floor to 6 the most rapid possibility is 7.92 seconds, while the most extended chance is 26.4 seconds. On the basement floor, the fastest opportunity is 9.9 seconds, while the most extended possibility is 19.8 seconds. 
Table 2. Accumulation Result of Evacuation Time

\begin{tabular}{|c|c|c|c|c|}
\hline Accum VA Time & Average & $\begin{array}{c}\text { Half } \\
\text { Width }\end{array}$ & $\begin{array}{l}\text { Minimum } \\
\text { Average }\end{array}$ & $\begin{array}{c}\text { Maximum } \\
\text { Average }\end{array}$ \\
\hline $\begin{array}{l}\text { Emergency Door to the } \\
\text { assembly point }\end{array}$ & 5672.28 & 57.85 & 5512.49 & 5779.10 \\
\hline To front door & 967.50 & 44.54 & 882.62 & 1056.45 \\
\hline Ramp (up) & 169.00 & 14.09 & 140.00 & 200.00 \\
\hline Basement Stair (up) & 297.63 & 22.65 & 246.82 & 341.71 \\
\hline $2^{\text {nd }}$-Floor Corridor & 74493.03 & 799.98 & 72767.99 & 75950.03 \\
\hline $5^{\text {th }}$-floor Corridor & 1759.84 & 51.76 & 1654.66 & 1883.98 \\
\hline Basement Corridor & 643.10 & 16.94 & 596.10 & 679.26 \\
\hline $1^{\text {st }}$-floor corridor & 1503.82 & 71.31 & 1351.11 & 1657.35 \\
\hline $3^{\text {rd }}$-floor corridor & 1759.72 & 74.57 & 1547.20 & 1895.24 \\
\hline $4^{\text {th }}$-floor corridor & 1778.21 & 87.1 & 1647.84 & 1988.55 \\
\hline $6^{\text {th }}$-floor corridor & 1769.37 & 60.89 & 1630.30 & 1916.06 \\
\hline $6^{\text {th }}$-floor stair (down) & 1551.28 & 33.42 & 1501.15 & 1630.86 \\
\hline $2^{\text {nd }}$-floor stair (down) & 11207.59 & 148.85 & 10877.71 & 11482.22 \\
\hline $3^{\text {rd }}$-floor stair (down) & 6140.12 & 101.30 & 5843.87 & 6314.02 \\
\hline $4^{\text {th }}$-floor stair (down) & 4642.72 & 58.98 & 4501.41 & 4772.58 \\
\hline $5^{\text {th }}$-floor stair (down) & 3061.13 & 58.3 & 2957.11 & 3187.95 \\
\hline General stair (down) & 3563.20 & 115.70 & 3377.45 & 3945.25 \\
\hline
\end{tabular}

From the modeling results obtained, the average total travel time required by all Kanaya Grand hotel visitors will be 5672.28 seconds or 94.53 minutes. This can be seen in the draft simulation results in the "Accumulated Time" column time from the emergency door to the assembly point (Table 2).

Based on existing standards, a building must last at least 60 minutes to anticipate evacuation with many people. Meanwhile, in the Grand Kanaya Hotel, it took 94.53 minutes to evacuate all visitors. So to increase the effectiveness of the Grand Kanaya Evacuation Line in accordance with the regulation of the Minister of Public Works No. 45/PRT/M/2007 and SNI 03-1746-2000 that more than 3 floors of buildings should have at least 2 emergency stairs, the floor plan recommended by the author is an additional recommendation for emergency stairs so that Grand Kanaya Hotel meets the applicable standards. 




Figure 15. Recommendation Addition of Emergency Stair on the South Side

With the addition of an emergency staircase on the south side (Figure 15), there is also an increase in the choice of emergency exits at Grand Kanaya Hotel to increase the effectiveness of the evacuation route in this hotel. The following table is the simulation result with the addition of an emergency staircase on the south side. 
Table 3. The Simulation Result of Addition Emergency Stair on the South Side

\begin{tabular}{|c|c|c|c|c|}
\hline Accum VA Time & Average & $\begin{array}{c}\text { Half } \\
\text { Width }\end{array}$ & $\begin{array}{c}\text { Minimum } \\
\text { Average }\end{array}$ & $\begin{array}{c}\text { Maximum } \\
\text { Average }\end{array}$ \\
\hline Basement Corridor & 656.82 & 26.77 & 623.17 & 681.05 \\
\hline To Exit 1 & 2033.47 & 161.66 & 1829.07 & 2176.26 \\
\hline To Exit 2 & 2027.76 & 191.31 & 1851.86 & 2162.44 \\
\hline Ramp (up) & 206.00 & 50.88 & 160.00 & 260.00 \\
\hline Stairs (up) & 245.53 & 83.08 & 161.67 & 328.73 \\
\hline Front Door & 2904.16 & 186.78 & 2690.68 & 3066.14 \\
\hline $3^{\text {rd }}$ Floor Stair 1 & 669.30 & 149.43 & 487.54 & 812.15 \\
\hline $4^{\text {th }}$ floor Stair 1 & 675.65 & 115.34 & 564.02 & 768.02 \\
\hline $5^{\text {th }}$ floor Stair 1 & 776.75 & 108.78 & 629.19 & 846.89 \\
\hline $6^{\text {th }}$ floor Stair 1 & 817.27 & 51.03 & 760.93 & 865.33 \\
\hline $2^{\text {nd }}$ floor Stair 1 & 4602.82 & 365.54 & 4216.01 & 4949.25 \\
\hline $2^{\text {nd }}$ floor Stair 2 & 4775.59 & 462.16 & 4376.16 & 5214.26 \\
\hline $3^{\text {rd }}$ floor Stair 2 & 823.42 & 85.94 & 704.80 & 881.43 \\
\hline $4^{\text {th }}$ floor Stair 2 & 794.40 & 60.58 & 751.55 & 868.06 \\
\hline $5^{\text {th }}$ floor Stair 2 & 835.73 & 121.05 & 743.77 & 1001.94 \\
\hline $6^{\text {th }}$ floor Stair 2 & 728.25 & 64.61 & 679.39 & 802.82 \\
\hline Stair (down) & 5318.34 & 306.82 & 5027.92 & 5636.54 \\
\hline $3^{\text {rd }}$ floor Stair 1 (down) & 2989.48 & 253.54 & 2719.93 & 3257.17 \\
\hline $4^{\text {th }}$ floor Stair 1 (down) & 2292.76 & 85.18 & 2171.91 & 2340.80 \\
\hline $5^{\text {th }}$ floor Stair 1 (down) & 1592.38 & 76.15 & 1502.58 & 1657.46 \\
\hline $6^{\text {th }}$ floor Stair 1 (down) & 807.03 & 59.30 & 743.93 & 853.28 \\
\hline Stair 2 (down) & 717.36 & 15.54 & 706.35 & 732.18 \\
\hline $6^{\text {th }}$ floor Stair 2 (down) & 3107.33 & 185.55 & 2923.19 & 3310.16 \\
\hline $5^{\text {th }}$ floor Stair 2 (down) & 1486.88 & 134.04 & 1329.19 & 1608.21 \\
\hline $4^{\text {th }}$ floor Stair 2 (down) & 2307.91 & 121.68 & 2183.34 & 2405.51 \\
\hline
\end{tabular}

It can be seen that the highest evacuation time is through the front door with 2904 seconds or 48 minutes (Table 3). With the recommendation of adding emergency stairs on the south side, the evacuation speed at Grand Kanaya Hotel increased by $48 \%$.

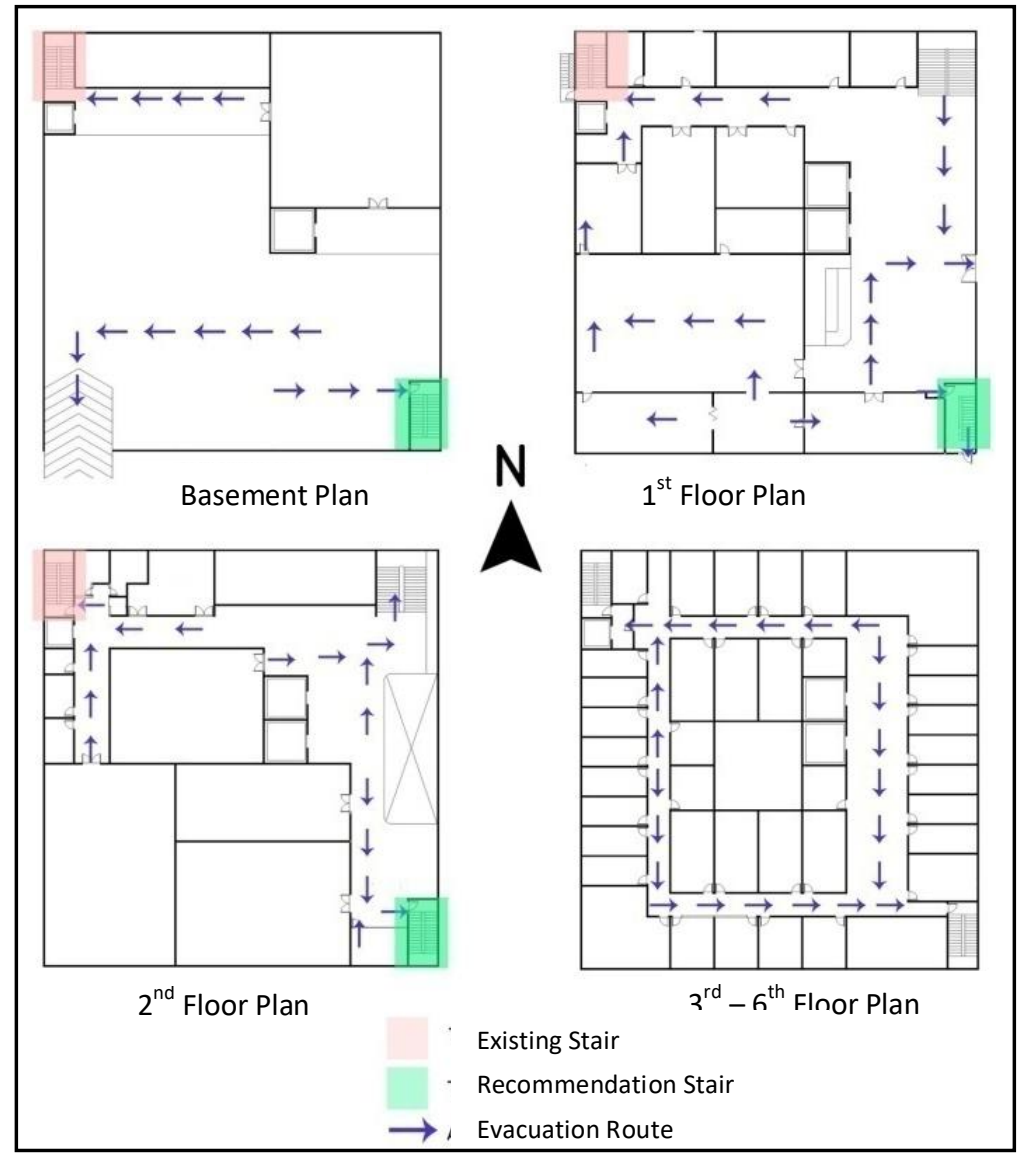

Figure 17. Recommendation Addition of Emergency Stair on the Southeast Side 
With the addition of an emergency staircase on the southeast side (Figure 17), there is also an increase in the choice of emergency exits at Grand Kanaya Hotel so that it can increase the effectiveness of the evacuation route in this hotel. The following table is the simulation result with the addition of emergency stairs on the southeast side.

Table 4. The Simulation Result of Addition Emergency Stair on the Southeast Side

\begin{tabular}{|c|c|c|c|c|}
\hline Accum VA Time & Average & $\begin{array}{c}\text { Half } \\
\text { Width }\end{array}$ & $\begin{array}{l}\text { Minimum } \\
\text { Average }\end{array}$ & $\begin{array}{c}\text { Maximum } \\
\text { Average }\end{array}$ \\
\hline Basement Corridor & 646.18 & 25.08 & 620.97 & 667.45 \\
\hline To Exit 1 & 2546.44 & 115.65 & 2430.10 & 2668.73 \\
\hline To Exit 2 & 1910.05 & 79.78 & 1840.16 & 1978.50 \\
\hline Ramp (up) & 194.00 & 71.10 & 120.00 & 260.00 \\
\hline Stairs (up) & 271.15 & 113.59 & 164.24 & 378.41 \\
\hline Front Door & 2436.09 & 177.55 & 2332.18 & 2680.57 \\
\hline $3^{\text {rd }}$ Floor Stair 1 & 968.73 & 136.54 & 860.66 & 1132.40 \\
\hline $4^{\text {th }}$ floor Stair 1 & 919.33 & 58.45 & 859.23 & 983.14 \\
\hline $5^{\text {th }}$ floor Stair 1 & 922.40 & 104.04 & 808.34 & 1033.39 \\
\hline $6^{\text {th }}$ floor Stair 1 & 943.37 & 76.36 & 865.43 & 1015.31 \\
\hline $2^{\text {nd }}$ floor Stair 1 & 5857.78 & 201.19 & 5622.92 & 6017.14 \\
\hline $2^{\text {nd }}$ floor Stair 2 & 4421.34 & 137.07 & 4289.14 & 4576.33 \\
\hline $3^{\text {rd }}$ floor Stair 2 & 602.31 & 115.79 & 493.78 & 736.25 \\
\hline $4^{\text {th }}$ floor Stair 2 & 661.72 & 103.58 & 543.30 & 754.97 \\
\hline $5^{\text {th }}$ floor Stair 2 & 600.39 & 89.45 & 476.20 & 651.34 \\
\hline $6^{\text {th }}$ floor Stair 2 & 583.21 & 30.07 & 551.64 & 610.39 \\
\hline Stair (down) & 4382.18 & 180.82 & 4253.34 & 4630.17 \\
\hline $3^{\text {rd }}$ floor Stair 1 (down) & 3687.80 & 125.72 & 3591.27 & 3851.14 \\
\hline $4^{\text {th }}$ floor Stair 1 (down) & 2747.88 & 210.57 & 2473.72 & 2890.57 \\
\hline $5^{\text {th }}$ floor Stair 1 (down) & 1851.50 & 103.25 & 1709.73 & 1927.72 \\
\hline $6^{\text {th }}$ floor Stair 1 (down) & 940.82 & 59.38 & 873.21 & 1007.89 \\
\hline Stair 2 (down) & 606.83 & 74.90 & 552.98 & 689.48 \\
\hline $3^{\text {th }}$ floor Stair 2 (down) & 2456.38 & 63.40 & 2376.53 & 2508.13 \\
\hline $5^{\text {th }}$ floor Stair 2 (down) & 1210.56 & 101.24 & 1123.48 & 1291.47 \\
\hline $4^{\text {th }}$ floor Stair 2 (down) & 1858.66 & 154.99 & 1691.98 & 2016.48 \\
\hline
\end{tabular}

It can be seen that the highest evacuation time is through Exit 1 with a time of 2546 seconds or 42 minutes (Table 4). With the recommendation of adding emergency stairs on the southeast side, the evacuation speed at Grand Kanaya Hotel increased by 55\%.

\section{Conclusion}

The use of Rockwell Arena software is sufficient enough to calculate the evacuation speed of Grand Kanaya hotel visitors because the Rockwell Arena software is a software that can simulate a system model with statistical data processing capabilities.

Based on the results of data processing using Rockwell Arena software, the evacuation speed of visitors at the Grand Kanaya Hotel has not been effective, which is 5672.28 seconds or 94.53 minutes. The evacuation time of Grand Kanaya Hotel does not meet the evacuation time requirement of 60 minutes. This is due to several elements of the evacuation route at the Grand Kanaya Hotel which do not meet the standards. Like, the maximum distance of the corridor on the 3rd to 6th floors reaches 51 meters. Besides, the minimum number of emergency stairs in buildings of more than three levels is two emergency stairs, but Grand Kanaya Hotel only has one emergency stair. 
By adding an emergency stair on the south side that is parallel to the existing emergency ladder, the evacuation speed can be increased by $48 \%$. From the initial evacuation speed, 94 minutes was reduced to 48 minutes. By adding emergency ladders on the southeast side which are located crossing with the existing emergency ladder, it can increase the evacuation speed by $55 \%$. From the initial evacuation speed, 94 minutes was reduced to 42 minutes.

The most effective recommendation is to adding stairs on the southeast side with the fastest evacuation time of 2546 seconds or 42 minutes.

\section{Acknowledgment}

The results of this research are expected to be useful for the hotel's owner and management to find out the problems on the evacuation route on hotel buildings.

\section{REFERENCES}

[1] S. W. F. A. Theresia Pynkyawati, "Kajian Desain Sirkulasi Ruang Dalam sebagai Sarana Evakuasi Kebakaran pada Bangunan Hotel Carrcadin Bandung," Itenas Rekayasa , p. 2, 2009.

[2] Peraturan Kepala Badan Nasional Penanggulangan Bencana No. 10 Tahun 2008, Pedoman Komando Tanggap Darurat Bencana, Jakarta.

[3] STOLLARD, Paul; ABRAHAMS, John. Fire from first principles: a design guide to building fire safety. Taylor \& Francis, 1999.

[4] Keputusan Menteri Pekerjaan Umum RI No. 10/KPTS/2000, Ketentuan Teknis Pengaman Terhadap Bahaya Kebakaran Pada Gedung Dan Lingkungan, Jakarta

[5]Peraturan Kepala Badan Nasional Penanggulangan Bencana No. 10 Tahun 2007, Pedoman Komando Tanggap Darurat Bencana, Jakarta.

[6] NFPA 101 life safety code. Quincy, MA: National Fire Protection Association, 2000.

[7]Badan Standarisasi Nasional. (2001). SNI 03-6574-2001, Tata Cara Perencanaan

Pencahayaan Darurat, Tanda Arah dan Sistem Peringatan Bahaya pada Bangunan Gedung, Badan Penerbit PU, Jakarta.

[8] E. Neufert, P. Neufert, and J. Kister,Architects data. Oxford: Wiley-Blackwell, 2012.

[9]Badan Standarisasi Nasional.(2000). SNI 03-1736-2000, Tata Cara Perencanaan Sistem

Proteksi Pasif Untuk Pencegahan Bahaya Kebakaran Pada Bangunan Rumah Dan Gedung, Badan Penerbit PU, Jakarta.

[10] Sugiyono, ( 2009 ). Metode Penelitian Kuantitatif, Kualitatif dan R\&D, Bandung : Alfabeta. 